\title{
Czy regularne trenowanie jogi może mieć związek z efektywniejszym radzeniem sobie ze stresem?
}

\section{Is training yoga regulary can have an effective impact on dealing with stress?}

\author{
Żaneta Ciosek¹, Daria Rusnarczyk², Aleksandra Szylińska¹, Karolina Kot³ ${ }^{3}$ Hanna Mosiejczuk¹, Iwona Rotter ${ }^{1}$ \\ ${ }^{1}$ Samodzielna Pracownia Rehabilitacji Medycznej Pomorskiego Uniwersytetu Medycznego w Szczecinie \\ ul. Grudziądzka 31, 70-103 Szczecin \\ Kierownik: dr n. med. Iwona Rotter
}

2 Studenckie Koło Naukowe przy Samodzielnej Pracowni Rehabilitacji Medycznej Pomorskiego Uniwersytetu Medycznego w Szczecinie ul. Grudziądzka 31, 70-103 Szczecin

Opiekun: dr n. med. Iwona Rotter

${ }^{3}$ Studenckie Koło Naukowe przy Katedrze i Zakładzie Biologii i Parazytologii Medycznej Pomorskiego Uniwersytetu Medycznego w Szczecinie al. Powstańców Wlkp. 72, 70-111 Szczecin

Opiekun: dr hab. n. med., prof. PUM Danuta Kosik-Bogacka

\begin{abstract}
SUMMARY
Introduction: The word yoga (Goya) is derived from the Sanskrit yii and means: bind, connect, attach and focus attention on something. It also means connection, and the union. The system of yoga has collected and systematized Patanjali in his "Yoga Sittrach" work. Yoga has the task of shaping proper physical culture and spirit (mind), regardless of religious beliefs, national origin, membership in a social group.

The aim of the study was to evaluate the relationship between yoga and regular coaching strategy for coping with stress, blood pressure and abdominal obesity.

Material and methods: The study involved 100 people divided into 2 groups. The first group comprised students regularly practicing yoga. The second group were randomly selected subjects not regularly engaged in sport. The age of the subjects ranged 18-60 years and over. Research material was gathered using a questionnaire designed by the authors, and the mini-COPE test. In addition, blood pressure and waist circumference were measured to assess the prevalence of abdominal obesity.
\end{abstract}

\section{STRESZCZENIE}

Wstęp: Słowo joga (Goya) pochodzi od sanskryckiego yij i oznacza: wiązać, łączyć, przywiązy wać i skupiać na czymś uwagę. Oznacza także połączenie oraz zjednoczenie. System jogi zebrał i usystematyzował Patańdżali w swojej pracy „Yoga Sittrach”. Joga ma za zadanie ukształtowanie właściwej kultury fizycznej i duchowej (umysł) bez względu na poglądy religijne, pochodzenie oraz przynależność do grupy społecznej.

Celem pracy była ocena zależności pomiędzy regularnym trenowaniem jogi a strategią radzenia sobie ze stresem, wartościami ciśnienia tętniczego i występowaniem otyłości brzusznej.

Materiał i metody: W badaniach wzięło udział 100 osób podzielonych na 2 grupy. Pierwsza to regularnie trenujący jogę uczniowie szkoły jogi. Druga to spontanicznie wybrane osoby nieuprawiające regularnie żadnego sportu. Badani byli w wieku 18-60 lat. Do uzyskania materiału badawczego uży to kwestionariusz ankiety własnego autorstwa oraz test mini-COPE. Ponadto wykonano badanie ciśnienia tętniczego krwi i obwodu pasa w celu oceny występowania otyłości brzusznej.
Results: Among people who practice yoga the average waist circumference was $82.8 \pm 8$ in women and $90.3 \pm 11$ in men $(p<0.034)$. A healthy waistline was found in $43(86 \%)$ subjects in the yoga group, and 34 (68\%) subjects in the control group. Body mass index (BMI) also falls in favour of yoga, and in this group 15 (30\%) more subjects had normal BMI. Abdominal obesity and BMI indicating obesity was found in 10 (20\%) subjects from the yoga group and 15 (30\%) from the control group. The study revealed no significant differences in mean blood pressure between the analysed groups.

Conclusions: Based on the analysis of the questionnaire mini-COPE people regularly Training Yoga choose more effective strategies for coping with stress. Regular practice of yoga is a factor in reducing abdominal obesity. Men who trains yoga have blood pressure lower than those who doesn't practice any sport.

Key words: yoga, stress, physical activity, strategies for coping with stress.
Wyniki: Wśród osób trenujących jogę zauważono średni mniejszy obwód talii u kobiet 82,8 \pm 8 w stosunku do mężczyzn 90,3 $\pm 11(\mathrm{p}=0,034)$. Prawidłowy obwód w pasie wykazano u 43 (86\%) osób trenujących jogę oraz u 34 (68\%) osób z grupy kontrolnej. Wskaźnik masy ciała (BMI) również wypadł na korzyść osób trenujących jogę, które przeważały liczebnie o 15 (30\%) osób w kategorii BMI w normie. Otyłość centralną i BMI wskazujące na otyłość w grupie jogi wykazano u 10 (20\%) osób, a w grupie kontrolnej u 15 (30\%) osób. W badaniach autorskich nie stwierdzono istotnej różnicy w średnim ciśnieniu badanych grup.

Wnioski: Na podstawie analizy kwestionariusza mini-COPE osoby regularnie trenujące jogę wybierają bardziej efektywne strategie radzenia sobie ze stresem. Regularne uprawianie jogi jest czynnikiem zmniejszającym otyłość brzuszną. Mężczyźni trenujący jogę mają wartości ciśnienia tętniczego niższe niż osoby nieuprawiające żadnego sportu.

Słowa kluczowe: joga, stres, aktywność fizyczna, strategie radzenia sobie ze stresem. 


\section{WSTĘP}

Dobroczynne działanie wysiłku fizycznego ma szczególnie ważne znaczenie w dzisiejszych czasach, kiedy coraz większa część populacji żyje coraz szybciej. To właśnie tempo życia może nasilać występowanie stresu [1], na który człowiek reaguje przede wszystkim na poziomie fizjologicznym. W sytuacji stresowej w organizmie dochodzi do zmian wskazujących na ogólną mobilizację zasobów energetycznych. Zmiany zachodzące na poziomie aktywacji są związane przede wszystkim z czynnością tworu siatkowatego pnia mózgu i posiadają dwa wymiary. Pierwszy, zwany aktywacyjnym, wiąże się ze zmianami w poziomie aktywacji kory mózgowej, natomiast drugi odnosi się do zmian w obrębie obwodowego układu nerwowego. Na podstawie badań wykazano zależności pomiędzy długotrwałym działaniem stresu a występowaniem nadciśnienia tętniczego. U osób wykazujących silniejsze reakcje organizmu ze strony układu sercowo-naczyniowego w wyniku działania stresu normalizacja podwyższonego ciśnienia tętniczego trwa dłużej. Wśród nich istnieje zwiększone ryzyko wystąpienia nadciśnienia tętniczego. Podobnie wśród osób narażonych na przewlekły stres również zauważa się częste występowanie otyłości centralnej, z kolei w wielu przypadkach otyłość zmniejsza się wraz ze spadkiem wysokości kortyzolu w organizmie, czyli zmniejszeniem czynnika stresującego [2].

Regularna aktywność fizyczna pozwala na modyfikację mechanizmów patofizjologicznych związanych ze stresem, jak również ma udokumentowany bezpośredni wpływ na funkcjonowanie ośrodkowego układu nerwowego [3]. Przykładem takiej aktywności jest joga. Słowo joga (Goya) pochodzi od sanskryckiego yij i oznacza: wiązać, łączyć, przywiązywać i skupiać na czymś uwagę. Oznacza także połączenie oraz zjednoczenie [4]. System jogi zebrał i usystematyzował Patańdżali w swojej pracy „Yoga Sittrach”. Joga to staroindyjski system wychowawczo-higieniczno-leczniczy, w skład którego, oprócz ćwiczeń jogi, wchodzi również filozofia jogi, ćwiczenia oddechowe, zalecenia higieniczne oraz relaksacja. Wszystkie elementy jogi przenikają się nawzajem. Korzyści można osiągnąć bez potrzeby wierzenia w jej zasady [5]. Joga ma za zadanie kształtować właściwą kulturę fizyczną i duchową (umysł) bez względu na poglądy religijne, pochodzenie oraz przynależność

TABELA 1. Stopnie i charakterystyka jogi

\begin{tabular}{|c|c|}
\hline Nazwa & Charakterystyka \\
\hline 1. Yama & Uniwersalne przykazania moralne \\
\hline 2. Niyama & Oczyszczanie siebie poprzez dyscyplinę \\
\hline 3. Asana & Pozycje - ćwiczenia \\
\hline 4. Pranayama & Rytmiczna kontrola oddechu \\
\hline 5. Pratyahara & $\begin{array}{l}\text { Wycofanie i wyzwolenie umysłu spod dominacji } \\
\text { zmysłów oraz zewnętrznych obiektów }\end{array}$ \\
\hline 6. Dharana & Koncentracja \\
\hline 7. Dhyana & Kontemplacja \\
\hline 8. Samandhi & $\begin{array}{l}\text { Stan nadświadomości osiągnięty w wyniku } \\
\text { głębokiej kontemplacji, w którym jogin jednoczy } \\
\text { się z obiektem swej kontemplacji, czyli ze swoim } \\
\text { centrum }\end{array}$ \\
\hline
\end{tabular}

do grupy społecznej [6]. Patańdżali wylicza 8 stopni czy też części jogi (tab. 1) [7].

Od wieków tradycja jogi jest przekazywana ustnie. Początki zainteresowania ową techniką sięgają XIX w., kiedy to orientalna myśl zaczęła przenikać na Zachód. Obecnie obserwuje się coraz większą liczbę powstających klubów sportowych, szkół i ośrodków propagujących jogę. Powiększająca się na przełomie ostatnich 10 lat liczba światowych badań naukowych dotyczących jogi jako systemu ćwiczeń fizycznych wykazuje istotne zalety zdrowotne jej systematycznego praktykowania. Na podstawie wyników badań wykazano poprawę siły i wytrzymałości oraz regulację zmiennych fizjologicznych m.in. ciśnienia krwi $[8,9,10]$. Pozycje przyjmowane w trakcie jogi zwiększają zakres ruchomości kręgosłupa, angażując mięśnie przykręgosłupowe, skośne brzucha i grzbietu, co wpływa na poprawę trawienia i wyszczupla talię, kształtując zgrabną sylwetkę. Światowe badania wskazują, że w 2004 r. ok. 200 mln ludzi (z wyłączeniem Indii) praktykowało jogę, w tym w Polsce 30-40 tys. osób [11]. Pomimo że istnieje wiele ścieżek czy też rodzajów jogi, wszystkie przenikają się nawzajem i mają na celu zjednoczenie ciała, umysłu oraz ducha.

Celem pracy była ocena zależności pomiędzy regularnym trenowaniem jogi a strategią radzenia sobie ze stresem, wartościami ciśnienia tętniczego i występowaniem otyłości brzusznej.

\section{MATERIAt I METODY}

Badania zostały przeprowadzone w szczecińskiej szkole jogi. Wzięło w nich udział 100 osób - 67 kobiet i 33 mężczyzn w wieku 18-6o lat, które zostały podzielone na grupę badaną oraz grupę kontrolną. Najwięcej badanych mieściło się w przedziale 35-44 lat. W grupie badanej znajdowało się 35 kobiet i 15 mężczyzn trenujące jogę minimum 1,5 roku (co najmniej 3 dni w tygodniu), natomiast grupę kontrolną stanowiło 50 losowo dobranych osób (32 kobiety i 18 mężczyzn) nieuprawiających regularnie żadnego sportu. Średni obwód w talii wszystkich badanych wyniósł $86,3 \pm 11,1$. Średnia wartość wskaźnika masy ciała (body mass index - BMI) w badanej grupie wyniosła 22,6 $\pm 2,9$. W badanej grupie średnia wartość ciśnienia skurczowego wyniosła $129 \pm 14,5$ oraz ciśnienia rozkurczowego $79,6 \pm 10,6$.

Przed rozpoczęciem badań każda osoba została poinformowana o ich przebiegu i wyraziła zgodę na udział. Pomiar obwodu na wysokości talii wykonano przy użyciu miary antropometrycznej, z kolei do pomiaru masy ciała i wzrostu wykorzystano standardową wagę lekarską. Wskaźnik masy ciała obliczony został według wzoru masy ciała w kilogramach podzielonej przez kwadrat wysokości w metrach. Ciśnienie tętnicze krwi zmierzono elektronicznym, zautomatyzowanym ciśnieniomierzem naramiennym Omron M3 Basic II (Polska).

Badania prowadzone były metodą sondażu diagnostycznego. W anonimowym kwestionariuszu ankiety znajdowały się 3 pytania zamknięte dotyczące płci, wieku, ciśnienia tętniczego z możliwością wybrania jednej prawidłowej odpowiedzi, jak 
również 3 pytania otwarte na temat wagi, wzrostu i uczęszczania na jogę. Dodatkowo użyto testu mini-COPE do oceny radzenia sobie ze stresem. Test mini-COPE składał się z 28 zdań twierdzących, które są odzwierciedleniem 14 strategii radzenia sobie ze stresem: aktywne radzenie sobie, planowanie, pozytywne przewartościowanie, akceptacja, poczucie humoru, zwrot ku religii, poszukiwanie wsparcia emocjonalnego, poszukiwanie wsparcia instrumentalnego, zajmowanie się czymś innym, zaprzeczanie, wyładowanie, zażywanie substancji psychoaktywnych, zaprzestanie działań, obwinianie siebie. Wyniki testu mini-COPE ocenia się w następujący sposób: 0 - prawie nigdy tak nie postępuję, 1 - rzadko tak postępuję, 2 - często tak postępuję, 3 - prawie zawsze tak postępuję. Punkty z dwóch stwierdzeń należących do jednej strategii sumuje się, a następnie uzyskany wynik dzieli się przez 2. Tak postępuje się z każdą z 14 strategii. Wyniki każdej ze skal mieszczą się w granicach 0-3.

Analizę statystyczną przeprowadzono z użyciem elementów statystyki opisowej, głównie średnich, odchyleń standardowych oraz minimum i maksimum. Do sprawdzenia normalności rozkładu zastosowano test W Shapiro-Wilka. Większość mierzonych parametrów ilościowych miała rozkład odbiegający od normalnego. Do porównania różnic pomiędzy osobami trenującymi a nietrenującymi jogę zastosowano nieparametryczny test U Manna-Whitneya. Istotność statystyczną przyjęto na poziomie $\mathrm{p}<0,05$. Analizę statystyczną wykonano przy użyciu pakietu statystycznego Statistica 12.

\section{WYNIKI}

Osoby trenujące jogę istotnie lepiej radziły sobie z akceptacją trudnych sytuacji, w której się znalazły. W grupie tej zauważono również znacznie mniejszy procent osób zażywających substancje psychoaktywne w sytuacjach stresowych. Wyraźnie widoczna jest dominacja w grupie osób trenujących jogę z technikami skutecznego radzenia sobie ze stresem. Grupa osób nietrenujących jogi zdobywa przewagę w przypadku pytań związanych z emocjami, ale nie wykazano istotności statystycznej (tab. 2).

W tabeli 3 zestawiono dane dotyczące obwodu w talii, BMI, wartości ciśnienia skurczowego i rozkurczowego z podziałem na dwie grupy osób uprawiających jogę oraz osób nieuprawiających żadnego sportu. Biorąc pod uwagę obwód w pasie, wykazano istotne statystycznie różnice względem płci. Wśród osób trenujących jogę zauważono średni mniejszy obwód talii wśród kobiet 82,8 \pm 8 w stosunku do mężczyzn 90,3 $\pm 11(p=0,034)$. Również wśród osób nieuprawiających żadnego sportu stwierdza się mniejszy obwód w talii u kobiet 84,2 \pm 10 niż u mężczyzn $93,9 \pm 14,4(\mathrm{p}=0,023)$. Prawidłowy obwód w pasie wykazano u 43 (86\%) osób z grupy jogi, natomiast z grupy kontrolnej u 34 (68\%) osób w tej kategorii. W grupie joginów otyłość centralną zauważono tylko u 7 (14\%) osób, a w grupie kontrolnej aż u 16 (32\%) osób.

Wśród kobiet uprawiających jogę co najmniej 3 razy w tygodniu średni wskaźnik BMI był niższy i wyniósł 21,83 $\pm 2,7$, natomiast u mężczyzn wyniósł 23,5 $\pm 3,92$. Z kolei u osób nieuprawiających żadnych sportów wskaźnik ten był wyższy u kobiet i wyniósł 22,09 $\pm 2,48$, a u mężczyzn 24,41 $\pm 2,26$ ( $p=0,004)$. Na podstawie wskaźnika BMI (powyżej $30 \mathrm{~kg} / \mathrm{m}^{2}$ ) zauważono

TABELA 2. Średnie ilości punktów uzyskanych w formularzu mini-COPE grupy jogi oraz grupy kontrolnej

\begin{tabular}{|c|c|c|c|c|c|c|c|}
\hline \multirow{3}{*}{$\begin{array}{l}\text { Strategie radzenia sobie } \\
\text { ze stresem }\end{array}$} & \multicolumn{6}{|c|}{ Średnia uzyskanych punktów od 0 do 3} & \multirow{3}{*}{ p } \\
\hline & \multicolumn{3}{|c|}{$\begin{array}{l}\text { osoby trenujące jogę } \\
\qquad n=50\end{array}$} & \multicolumn{3}{|c|}{$\begin{array}{l}\text { osoby nieuprawiające żadnych } \\
\text { sportów } \\
n=50\end{array}$} & \\
\hline & $\begin{array}{l}\text { kobiety } \\
n=35\end{array}$ & $\begin{array}{l}\text { mężczyźni } \\
\text { n = } 15\end{array}$ & ogółem & $\begin{array}{c}\text { kobiety } \\
n=32\end{array}$ & $\begin{array}{l}\text { mężczyźni } \\
n=18\end{array}$ & ogółem & \\
\hline Aktywne radzenie sobie & 2,37 & 2,37 & 2,37 & 2,0 & 2,0 & 2 & 0,18 \\
\hline Planowanie & 2,41 & 2,37 & 2,4 & 2,25 & 2,17 & 2,2 & 0,96 \\
\hline Pozytywne przewartościowanie & 1,97 & 2,3 & 2,07 & 1,77 & 1,28 & 1,59 & 0,01 \\
\hline Akceptacja & 2,06 & 1,7 & 1,95 & 2,53 & 2,31 & 2,45 & $<0,001$ \\
\hline Poczucie humoru & 1,07 & 1,1 & 1,08 & 0,53 & 0,86 & 0,65 & 0,004 \\
\hline Zwrot ku religii/medytacja & 1,4 & 1,4 & 1,4 & 1,56 & 1,06 & 1,38 & 0,74 \\
\hline Poszukiwanie wsparcia emocjonalnego & 1,97 & 1,7 & 1,89 & 1,69 & 1,31 & 1,55 & 0,07 \\
\hline Zajmowanie się czymś innym & 1,49 & 1,17 & 1,39 & 2,03 & 1,81 & 1,95 & 0,001 \\
\hline Zaprzeczanie & 0,51 & 0,7 & 0,57 & 1,2 & 0,58 & 0,98 & 0,15 \\
\hline Wytadowanie & 1,33 & 0,97 & 1,22 & 1,79 & 1,31 & 1,62 & 0,004 \\
\hline Zażywanie substancji psychoaktywnych & 0,42 & 0,43 & 0,43 & 1,5 & 1,22 & 1,4 & $<0,001$ \\
\hline Zaprzestanie działań & 0,62 & 0,37 & 0,54 & 0,79 & 0,61 & 0,73 & 0,28 \\
\hline Obwinianie siebie & 1,2 & 0,73 & 1,06 & 1,83 & 1,19 & 1,6 & 0,004 \\
\hline
\end{tabular}


TABELA 3. Średnie wartości i odchylenia standardowe badanych cech z podziałem na grupy

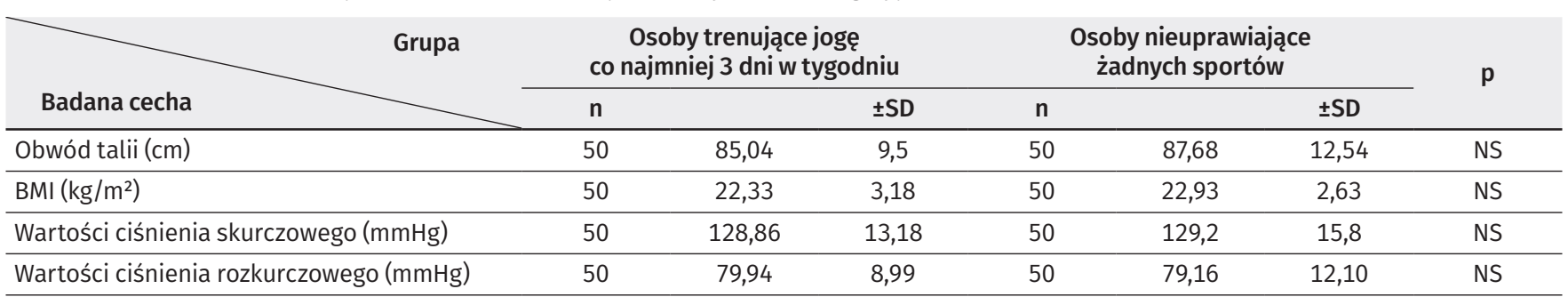

TABELA 4. Zakres wartości badanych cech w zależności od płci

\begin{tabular}{|c|c|c|c|c|c|c|c|c|c|c|c|c|c|c|}
\hline \multirow[b]{3}{*}{ Badana cecha } & \multicolumn{7}{|c|}{ Osoby trenujące jogę co najmniej 3 dni w tygodniu } & \multicolumn{7}{|c|}{ Osoby nieuprawiające żadnych sportów } \\
\hline & \multicolumn{3}{|c|}{ kobiety $(n=35)$} & \multicolumn{3}{|c|}{ mężczyźni (n = 15) } & \multirow[b]{2}{*}{$p$} & \multicolumn{3}{|c|}{ kobiety $(n=32)$} & \multicolumn{3}{|c|}{ mężczyźni (n = 18) } & \multirow[b]{2}{*}{ p } \\
\hline & $\pm S D$ & $\min$. & maks. & $\pm S D$ & $\min$. & maks. & & $\pm S D$ & $\min$. & maks. & $\pm S D$ & $\min$. & maks. & \\
\hline Obwód talii (cm) & $82,8 \pm 8$ & 71 & 100 & $90,3 \pm 11$ & 70 & 105 & 0,03 & $84,2 \pm 10$ & 69 & 102 & $93,9 \pm 14$ & 70 & 120 & 0,007 \\
\hline $\mathrm{BMI}\left(\mathrm{kg} / \mathrm{m}^{2}\right)$ & $21,8 \pm 3$ & 17 & 28 & $23,5 \pm 4$ & 18 & 30 & 0,16 & $22,1 \pm 2$ & 18 & 26 & $24,4 \pm 2$ & 20 & 28 & 0,002 \\
\hline $\begin{array}{l}\text { Wartości ciśnienia } \\
\text { skurczowego (mmHg) }\end{array}$ & $126,7 \pm 11$ & 111 & 157 & $133,9 \pm 16$ & 105 & 163 & 0,17 & $124,1 \pm 14$ & 95 & 156 & $138,2 \pm 16$ & 119 & 181 & 0,002 \\
\hline $\begin{array}{l}\text { Wartości ciśnienia } \\
\text { rozkurczowego (mmHg) }\end{array}$ & $79,3 \pm 9$ & 62 & 97 & $81,4 \pm 8$ & 65 & 96 & 0,46 & $76,4 \pm 12$ & 50 & 95 & $84 \pm 11$ & 57 & 102 & 0,03 \\
\hline
\end{tabular}

mniej badanych z otyłością w grupie jogi - 10 (20\%) osób, natomiast w grupie kontrolnej aż 15 (30\%) osób.

W grupie kobiet trenujących średnie wartości ciśnienia tętniczego: skurczowego - $126 \pm 11 \mathrm{mmHg}$ i rozkurczowego $79 \pm 9 \mathrm{mmHg}$ były niższe niż w tej samej grupie u mężczyzn odpowiednio $133 \pm 16 \mathrm{mmHg}$ i $81 \pm 8 \mathrm{mmHg}$. W grupie kobiet nietrenujących wartości ciśnienia tętniczego wyniosły: skurczowego $124 \pm 13 \mathrm{mmHg}$ i rozkurczowego $76 \pm 11 \mathrm{mmHg}$, a u mężczyzn odpowiednio $138 \pm 15 \mathrm{mmHg}$ i $84 \pm 11 \mathrm{mmHg}(\mathrm{p}=0,003)$. Prawidłowe ciśnienie tętnicze zauważa się u 16 (32\%) osób w grupie jogi, natomiast u 15 (30\%) osób w grupie nieuprawiających żadnego sportu. Nadciśnienie tętnicze w grupie I zauważono u 9 (18\%) osób, a w grupie II u 14 (28\%) osób (tab. 4).

\section{DYSKUSJA}

W literaturze przedmiotu jest wiele badań na temat stresu, nadciśnienia i otyłości, a także sposobów ich eliminacji za pomocą ćwiczeń związanych z praktyką jogi. Badania te często są trudne do porównania ze względu na ich różnorodność i metodologię. Decyduje o tym typ przeprowadzonych badań, zakres tematyczny oraz forma pytań, inne grupy wiekowe i społeczne biorące w nich udział. Wiele badań związanych tematycznie z jogą można spotkać wśród autorów z USA oraz Indii i Chin. Mnogość tych prac daje perspektywę rozwoju tej tematyki również w Polsce, gdzie grono badaczy jest dość ścisłe.

W badaniach autorskich nie stwierdza się istotnej różnicy w średnich wartościach ciśnienia tętniczego badanych grup. Jednakże istnieje znaczna przewaga osób w grupie ciśnienia optymalnego o 4 (8\%) osoby w grupie joginów. Ponadto nie występują w niej osoby z II bądź III stopniem nadciśnienia w przeciwieństwie do grupy kontrolnej, gdzie odnotowano po 2 osoby kolejno w II i III stopniu. Kulmatycki przeprowadził trening relaksacyjny wg technik jogi z udziałem 16 osób w wieku 35-65 lat z podwyższonym ciśnieniem (rozpiętość 140-175 mmHg dla skurczowego i 80-105 mmHg dla rozkurczowego); 10 osób brało leki (6 regularnie, 4 nieregularnie). Trening prowadzony był w ramach programu promocji zdrowia i profilaktyki chorób serca przez South Western Sydney Health Service przez 10 tygodni. Program treningu na podstawie ćwiczeń jogi proponowany w Kaivalyadhama i Bihar School of Yoga obejmował rozciąganie i przyjmowanie określonych pozycji ciała (pawanmuktasany i asany), ćwiczenia oddechowe (nadisodhana, ujjayi), ćwiczenia koncentracji umysłu (dharana) i relaksacji (joga nidra). Po 9 tygodniach praktyki relaksacyjnych ćwiczeń wg jogi wykonano 134 pomiary (16 osób × 9 spotkań - 10 nieobecności), gdzie większość (94) wskazywała na redukcje zarówno ciśnienia skurczowego, jak i rozkurczowego. Ćwiczenia spowodowały średnie (dla całej grupy) obniżenie ciśnienia skurczowego o $9 \mathrm{mmHg}$ i rozkurczowego o $5 \mathrm{mmHg}$ [12]. Wolff $i$ wsp. przeprowadzili badania na 83 osobach między 20. a 80. r.ż. chorujące na nadciśnienie. Podzielono ich na trzy grupy: uprawiających jogę na zajęciach z nauczycielem, ćwiczących jogę w domu oraz niećwiczących jogi. Po 12-tygodniowym treningu w grupie ćwiczących jogę w domu stwierdzono obniżenie ciśnienia skurczowego krwi o średnio 4,4 mmHg [13]. Bhavanani i wsp. zbadali 29 chorych na nadciśnienie i stwierdzili, że już po 5 minutach ćwiczeń pranayamy ich ciśnienie obniżyło się $(\mathrm{p}=0,05)[14]$. W badaniach Altman i Elaine z $2001 \mathrm{r}$. wykazano znaczne zmniejszenie ciśnienia skurczowego krwi oraz poziomu stresu w trakcie 4-tygodniowej praktyki ćwiczeń oddechowych, medytacyjnych oraz ćwiczeń rozciągających opartych na systemie jogi [15]. Pal i wsp. zbadali 258 pacjentów z Oddziału Kardiologicznego Uniwersytetu Medycznego w Chhatrapati Shahuji Maharaj. Wszyscy cierpieli na chorobę wieńcową. Badanych podzielono 
na dwie grupy. Jedna praktykowała jogę przez 18 miesięcy, druga nie. Po zakończeniu badania w grupie uprawiającej jogę odnotowano spadek masy ciała, obniżenie ciśnienia skurczowego oraz rozkurczowego krwi, w przeciwieństwie do drugiej grupy [16]. Badanie te są zgodne z badaniami autorskimi, które wykazują, iż jogini posiadają średnią wagę niższą o 3 kg od grupy badanej, przy BMI niższym o 0,2 oraz obwód w pasie mniejszy dla kobiet $01 \mathrm{~cm}$, a dla mężczyzn o $4 \mathrm{~cm}$. Warto zauważyć przy tym, iż spośród osób trenujących jogę najbardziej liczną grupą były kobiety w wieku 35-44 lat oraz mężczyźni w wieku 45-55 lat, co predysponuje do wzrostu wagi i ciśnienia, a w grupie kontrolnej zarówno wśród mężczyzn, jak i kobiet najliczniejszą grupę stanowiły osoby w wieku 25-34 lat. Brown i Gerbarg zbadali dwie grupy kolarzy juniorów. Jedna poddana była sesji jogi przed zawodami, druga nie. Badania opierały się na kontroli pulsu jako wyznacznika poziomu stresu. $\mathrm{W}$ badaniach wykazano, że grupa objęta sesją jogi miała o 20\% niższy puls niż grupa niepoddana sesji [17]. Huang i wsp. przebadali 63 kobiety w średnim wieku, które zostały podzielone na dwie grupy - jedna z 8-tygodniowym kursem jogi, druga - bez. Badano poziom stresu za pomocą The Perceived Stress Scale $\left(\mathrm{PSS}^{-10}\right.$ ) oraz pomiaru tętna. Po odbytym kursie stwierdzono lepsze radzenie sobie z sytuacjami stresowymi oraz niższe tętno w porównaniu z wynikami wyjściowymi u kobiet ćwiczących jogę. W grupie kontrolnej nie stwierdzono istotnych różnic [18]. Podobne badania na pracownikach urzędu przeprowadzili Hartfiel i wsp., którzy podzielili badanych na dwie grupy (z 8-tygodniowym kursem jogi i bez). Poziom stresu został sprawdzony za pomocą skali PSS $^{-10}$ oraz dodatkowo subiektywny poziom odczuwania stresu. Po 8-tygodniowej praktyce stwierdzono, że w porównaniu do grupy kontrolnej, grupa praktykująca jogę wykazała znaczne obniżenie poziomu stresu w skali PSS ${ }^{-10}$ oraz subiektywnego odczuwania stresu [19]. Kulmatycki i wsp. zbadali grupę 72 studentów (61 kobiet i 8 mężczyzn), którzy zostali losowo przydzieleni do jednej z trzech grup: 1) posturalnej jogi, 2) relaksacji progresywnej, 3) pasywnej relaksacji z muzyką (kontrolna). Studenci wzięli udział w 6 sesjach trwających po $60 \mathrm{~min}$. W badaniu posłużono się Skalą subiektywnego poczucia napięcia (SSPN) oraz Inwentarzem Spielbergera do badania lęku jako stanu (STAI). Końcowe rezultaty wskazują na to, ze dwie eksperymentalne grupy miały niższy poziom napięcia i lęku, natomiast poziom energii wzrósł najbardziej w grupie jogi (statystycznie istotnie, $p<0.05$ ). Grupa jogi posturalnej jest w porównaniu do relaksacji Jacobsona bardziej efektywna [20]. Można tu nawiązać do badań autorskich, gdzie grupa badana (osoby trenujące jogę) w formularzu mini-COPE (badającym style radzenia sobie ze stresem) wybierała znacznie częściej style efektywniejsze od grupy kontrolnej, np.: akceptacja 2 pkt na 3 możliwe, tymczasem grupa kontrolna 2,5 pkt na 3 możliwe; zażywanie substancji psychoaktywnych w grupie osób trenujących jogę to 0,4 pkt, a w grupie kontrolnej 1,4 pkt na 3 możliwe. Warto również nawiązać do Sharma i wsp., którzy sprawdzili wpływ praktyki szybkiej i wolnej pranayamy wśród zdrowych studentów. Na podstawie badań wykazano, że w grupie osób trenujących wolną (Kapalabhati, Bhastrika, Kukkuriya
Pranayama) i szybką (Nadishodhana, Savitri, Pranav Paranayama) po 12 tygodniach spadł poziom stresu (badany za pomocą skali PSS ${ }^{-10}$ ), jednak tylko w grupie wolnej pranayamy doszło do istotnego spadku ciśnienie tętniczego skurczowego i rozkurczowego [21]. Romanowski i wsp. przebadali pod względem fizjologicznym i psychologicznym praktykujących jogę. Wskazali na uzyskanie neurowegetatywnej równowagi u praktykujących jogę z przewagą dominacji układu parasympatycznego oraz bardziej efektywnej pracy metabolicznej organizmu. Z psychologicznego punktu badań u praktykujących zauważono poprawę nastroju, redukcje poziomu lęku oraz ogólne psychologiczne zintegrowanie [22]. Grabara i Szopa przeprowadzili badania, które objęły 32 kobiety i 10 mężczyzn w wieku 19-64 lat. Pod uwagę brali m.in. wskaźnik względnej masy ciała. Przeprowadzono również badania ankietowe dotyczące subiektywnego odczucia wpływu ćwiczeń hatha-jogi na stan zdrowia. Wykazano ogólną poprawę samopoczucia i zdrowia, zwiększenie wytrzymałości oraz odporności organizmu, poprawę gibkości, wzmocnienie mięśni, kontrolę lub zmniejszenie bólu w różnych dolegliwościach, poprawę funkcjonowania narządów wewnętrznych, spadek masy ciała, odtłuszczenie ciała i uregulowanie przemiany materii, zwiększenie poczucia subiektywnej energii, psychicznej koncentracji [23]. Powyższe badania mają odzwierciedlenie w badaniach autorskich, w których badani wykazują dużo lepsze radzenie sobie ze stresem niż grupa kontrolna, a oparte jest ono na technikach skoncentrowanych na rozwiązaniu problemu i unikaniu zachowań samodestrukcyjnych, takich jak zażywanie substancji psychoaktywnych, samoobwinianie się czy rezygnacja z osiągnięcia celu. Ma to swoje źródła w większej równowadze psychicznej, opanowaniu i aktywnej zaradności w sytuacjach stresowych.

\section{WNIOSKI}

Na podstawie analizy kwestionariusza mini-COPE stwierdzono, że osoby regularnie trenujące jogę wybierają bardziej efektywne strategie radzenia sobie ze stresem. Regularne uprawianie jogi jest czynnikiem zmniejszającym otyłość brzuszną. Mężczyźni trenujący jogę mają wartości ciśnienia tętniczego niższe niż osoby nieuprawiające żadnego sportu.

\section{PIŚMIENNICTWO}

1. Ackerman K.D., Heyman R., Rabin B.S., Anderson B.P., Houck P.R., Frank E. et al:: Stressful life events precede exacerbations of multiple sclerosis. Psychosom Med. 2002, 64, 916-920.

2. Bauer M.E., Perks P., Lightman S.L., Shanks N.: Restraint stress is associated with changes in glucocorticoid immunoregulation. Physiol Behav. $2001,73,525-532$.

3. Carrasco G.A., Van de Kar L.D.: Neuroendocrine pharmacology of stress. Eur J Pharmacol. 2003, 463, 235-272.

4. Palica D., Zwierzchowska A.: Terapeutyczne walory systemu jogi-przegląd piśmiennictwa. Hygeia Public Health. 2012, 47 (4), 418-423.

5. Smith C., Hancock H., Blake-Mortimer J., Eckert K.: A randomized comparative trial of yoga and relaxation to reduce stress and anxiety. Complement Ther Med. 2007, 15, 77-83. 
6. Streeter C.C., Jensen J.E., Perlmutter R.M., Cabral H.J., Tian H., TerhuneD.B. et al: Yoga Asana sessions increase brain GABA levels: a pilot study. J Altern Complement Med. 2007, 13, 419-426.

7. Górna J., Szopa J.: Rekreacyjne ćwiczenia jogi w kształtowaniu zdrowego stylu życia. In: Turystyka i sport dla wszystkich w promocji zdrowego stylu życia. Eds: W. Gaworecki, Z. Mroczyński, Wyd. Wyższej Szkoły Turystyki i Hotelarstwa w Gdańsku, Gdańsk 2008.

8. Bernardi L., Porta C., Spicuzza L., Bellwon J., Spadacini G., Frey AW. et al.: Slow breathing increases arterial baroreflex sensitivity in patients with chronic heart failure. Circulation. 2002, 105, 143-145.

9. Garfinkel M.S., Singhal A., Katz W.A., Allan D.A., Reshetar R., Schumacher H.R.: Yoga-based intervention for carpal tunnel syndrome: A randomized trial. JAMA. 1998, 280, 1601-1603.

10. Joshi L.N., Joshi V.D., Gokhale L.V.: Effect of short term Pranayam practice on breathing rate and ventilatory functions of lung. Indian J Physiol Pharmacol. 1992, 36, 105-108.

11. Bera T.K., Rajapurkar M.V.: Body composition, cardiovascular endurance and anaerobic power of yogic practitioners. Indian J Physiol Pharmacol. 1993, 37, 225-228.

12. Kulmatycki L.: Wpływ treningu relaksacyjnego jogi na obniżenie ciśnienia tętniczego. Post Rehab. 1993, 7 (4), 55-60.

13. Wolff M., Sundquist K., Larsson Lönn S., Midlöv P.: Impact of yoga on blood pressure and quality of life in patients with hypertension - a controlled trial in primary care, matched for systolic blood pressure. BMC Cardiovasc Disord. 2013, 13, 111.

14. Bhavanani A.B., Mohan M., Sanjay Z., Basavaraddi A.B.: Immediate cardiovascular effects of pranava pranayama in hypertensive patients. Indian J Physiol Pharmacol. 2012, 56 (3), 273-278.

15. Altman K., Elaine R.: A brief therapy model to reduce stress by practicing breathing exercises, mindful meditation, and yoga stretching. Disserta- tionn Abstracts International: Section B: The Sciences and Engineering. 2001, 62 (1-B), 530

16. Pal A., Srivastava N., Narain V.S., Agrawal G.G., Rani M.: Effect of yogic intervention on the autonomic nervous system in the patients with coronary artery disease: a randomized controlled trial. East Mediterr Health J. 2013, 19 (5), 452-458.

17. Brown R.P., Gerbarg P.L.: Sudarshan kriya yogic breathing in the treatment of stress, anxiety, and depression: part I - neurophysiologic model. J Altern Complement Med. 2005, 11 (1), 189-201.

18. Huang F.J., Chien D.K., Chung U.L.: Effects of Hatha yoga on stress in middle-aged women. J Nurs Res. 2013, 21 (1) 59-66.

19. Hartfiel N., Burton C., Rycroft-Malone J., Clarke G.., Havenhand J., Khalsa S.B. et al.: Yoga for reducing perceived stress and back pain at work. Occup Med (Lond). 2012, 62 (8), 606-612.

20. Kulmatycki L., Surynt A., Torzyńska K.: Relaksacja posturalna jogi a relaksacja progresywna w radzeniu sobie z lękiem i napięciem. In: Physical activity in disease prevention and heath promotion. Ed. B. Bergier. Institute of Health, Państwowa Wyższa Szkoła, Biała Podlaska 2010, 149-158.

21. Sharma V.K., Trakroo M., Subramaniam V., Rajajeyakumar M., Bhavanani A.B., Sahai A.: Effect of fast and slow pranayama on perceived stress and cardiovascular parameters in young health-care students. Int J Yoga. 2013, 6 (2), 104-110.

22. Romanowski W., Pasek T., Szwarc H., Gradowska T., Turos B., Sikora J. et al.: Próba fizjologicznej i psychologicznej oceny wpływu na organizm ćwiczeń wg systemu. Wychow Fiz Sport. 1969, 3, 139-170.

23. Grabara M., Szopa J.: Wpływ hatha-jogi na stan zdrowia ćwiczących. In: $5^{\text {th }}$ International Conference Movement and Health. Opole University of Technology, Opole 2006, 235-241. 